Diyala Journal of Engineering Sciences

Journal homepage: https://en.enginmag.uodiyala.edu.iq/

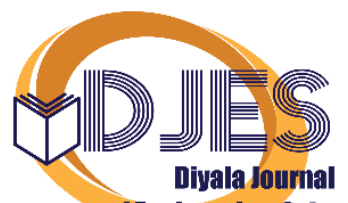

Diyala Journal

ISSN: 1999-8716 (Print); 2616-6909 (Online)

of Engineering Sciences

\title{
Experimental Assessment of Combining Geothermal with Conventional Air Conditioner Regarding Energy Consumption in Summer and Winter
}

\author{
Hazim N. Abed *, Ahmed Al-Samari \\ Department of Mechanical Engineering, University of Diyala, Iraq.
}

\begin{tabular}{ll} 
ARTICLE INFO & ABSTRACT \\
\hline $\begin{array}{l}\text { Article history: } \\
\text { Received 18 June 2021 }\end{array}$ & $\begin{array}{l}\text { The objectives of this study are to evaluate the use of geothermal energy combined with } \\
\text { conventional air-conditioner (A/C) and its contribution to reducing dependence on } \\
\text { electrical energy. Assessment of geothermal sources in Diyala governorate. This }\end{array}$ \\
Keywords: & $\begin{array}{l}\text { experiment includes installing a combined system in the test room. The indoor and } \\
\text { outdoor temperatures and relative humidity were calculated, as well as the calculation } \\
\text { of borehole temperature, in addition to the energy efficiency ratio (EER) and coefficient } \\
\text { of performance }(\mathrm{COP}) \text { of the systems. The amount of electricity consumption in } \mathrm{kWh} \\
\text { was calculated. The most important findings in this experiment are: }(1) \text { The temperature } \\
\left.\text { of the well at a depth of }(6 \mathrm{~m}) \text { is almost constant throughout the year, about } 24^{\circ} \mathrm{C} . \text { ( }^{2}\right)\end{array}$ \\
$\begin{array}{l}\text { Using the geothermal system alone in the test-room reduces the average indoor } \\
\text { temperature by } 8^{\circ} \mathrm{C} \text { within one day. (3) Iraq can benefit from the important geothermal } \\
\text { energy and its sources; however, its use is still very limited and limited to scientific } \\
\text { consumption; Borehole; Combined } \\
\text { system }\end{array}$ & $\begin{array}{l}\text { research only. (4) The experiment proved that the EER and COP of the geothermal } \\
\text { system, the combined system and the window-type air-conditioner are } 18.9,9.8,9.4,\end{array}$ \\
$5.54,1.9$ and 1.52 respectively.
\end{tabular}

\section{Introduction}

The energy crisis is considered one of the most important challenges facing humanity, along with wars, poverty, famine and others. Energy use should be greatly reduced and legalized due to the impact of fossil fuels on the environment and climate, as well as the limitations of traditional energy sources [1]. The first thing that must be done to achieve this goal is to change our behavior in terms of use and dispensing: avoiding the use of vehicles and cars, avoiding trash, etc. The second step that must be taken to reduce energy consumption is to increase the energy efficiency of cars and systems and make greater use of renewable energy sources [1].

The European Union (EU) has taken binding measures for its members, in accordance with the Kyoto Protocol, which stipulated that the global temperature rise by $\left(2^{\circ} \mathrm{C}\right)$ should be reduced by reaching the 20/20/20 target in 2020 . This goal stipulated a reduction in energy use by an amount of $20 \%$ in EU countries, increasing the use of renewable energy by $20 \%$ of the total energy used in the EU, and increasing energy efficiency by $20 \%$. By the year 2030, the EU aspires to achieve a reduction in greenhouse gases (GHG) emissions by $40 \%$ less than in 1990 , energy savings greater or equal to $27 \%$, and the use of renewable energy such as geothermal energy, wind, etc., by at least $27 \%$ $[1,2]$.

\author{
Nomenclature \\ $\mathrm{q}$ heat transfer rate (Watt) \\ $\dot{\mathrm{m}}$ mass flowrate $(\mathrm{kg} / \mathrm{sec}$.) \\ $\mathrm{Cp} \quad$ Specific heat capacity (W.s / kg. ${ }^{\circ} \mathrm{C}$ )
}

\footnotetext{
* Corresponding author.

E-mail address: eng_grad_mech018@uodiyala.edu.iq

DOI: $10.24237 /$ djes.2021.14308
} 
Te temperature at exit $\left({ }^{\circ} \mathrm{C}\right)$

Ti temperature at inlet $\left({ }^{\circ} \mathrm{C}\right)$

$\mathrm{QH}_{\mathrm{H}}$ heat transferred to a heated zone (Watt)

Qc heat transferred to a cooled zone (Watt)

W work consumed by the system (Watt)

$\begin{array}{ll}\text { Abbreviations } \\ \text { Btu/h } & \text { British thermal unit per hour } \\ \text { RH } & \text { relative humidity } \\ \text { A/C } & \text { conventional air-conditioner } \\ \text { EER } & \text { energy efficiency ratio } \\ \text { COP } & \text { coefficient of performance } \\ \text { EU } & \text { European Union } \\ \text { GHG } & \text { greenhouse gases } \\ \text { GSHP } & \text { ground source heat pump } \\ \text { GHEs } & \text { ground heat exchangers } \\ \text { ASHP } & \text { air-source heat pump } \\ \text { KSA } & \text { Kingdom of Saudi Arabia } \\ \text { CCP } & \text { chilled-ceiling panel } \\ \text { GHP } & \text { geothermal heat pump } \\ \text { NT\$ } & \text { New Thailand Dollars } \\ \text { GLD } & \text { Ground-Loop Design } \\ \text { NPV } & \text { net present value } \\ \text { PBT } & \text { payback time } \\ \text { HAP } & \text { hourly analysis program }\end{array}$

Reaching these ambitious goals requires improving the construction sector. Buildings in the EU consume $40 \%$ of total the energy used, of which half of it is consumed in heating and cooling [2, 3].

Hot springs are a form of geothermal energy and have been used since humankind's inception for bathing and healing purposes. As early as the first century A.D, the Romans used hot springs to heat buildings, as indicated by the ruins of the baths in Baden-Baden, Germany. These bathrooms are equipped with a heating system that uses ground water for floor heating [4].

Geothermal energy, in addition to its uses in bathrooms and resorts, at the present time it has many other uses, including the generation of electricity, heating and cooling by using ground source heat pump (GSHP) systems, of which 1.3 million units were installed in Europe in 2015 [5]. GSHP system mainly consists of a group of ground heat exchangers (GHEs) coupled with a water pump unit that circulates water through GHE to effect the heat exchange between the fluid and the formation of the ground [6].
Thermal performance has a great influence on the performance of heating and cooling system. The closed-loop vertical GHE type is the most widely used due to its excellent efficiency $[7,8]$. A single or double U-shaped tube is prepared for closed-loop GHE and placed in a borehole with a diameter of $10-30 \mathrm{~cm}$ and drilling depth of 50$200 \mathrm{~m}$, but one of the disadvantages of vertical closed loop GHE is its need for additional construction space and high cost resulting from drilling requirements [8, 9]. Another type of GHE has emerged that has garnered public interest in recent times and is associated with underground thermally active structures such as diaphragm walls, piles, tunnels, and concrete slabs $[8,10,11]$.

Many studies have been conducted on the use of geothermal sources in heating and cooling from the twentieth century to the present in countries with cold and extremely cold climates, but they are limited in extremely hot and dry climates. The following are some studies related to that:

Al-Shehri et al. [12] conducted a study in dry and hot regions on air-source heat pump (ASHP) and GSHP and their economic feasibility through conducting a technical and economic analysis of them. The study was conducted in the Kingdom of Saudi Arabia (KSA), which has a hot and dry climate. To make a comparison between the two systems to find out which is better in practical and economic terms, the following calculations were made [12]:

1. Calculating the cost of capital.

2. Calculating the cost of energy saved.

3. Calculating the cost of ground loops.

4. Calculate the payback period.

The results obtained showed that the GSHP system is economically feasible because the total costs are much lower than ASHP and also reduces carbon dioxide $\left(\mathrm{CO}_{2}\right)$ emissions [12]. The payback of the capital is about (10-20) years and it is considered and depends on the conditions of installation, climatic conditions and the thermal properties of the soil. The total cost of GSHP system saved over 22 years and when the soil temperature is $26^{\circ} \mathrm{C}$ will be $46 \%$, while when the soil temperature is $29^{\circ} \mathrm{C}$ for the same period of time it will be $37 \%$. GSHP 
consumes electricity on an annual basis, at a rate of $34.6 \%$ less than ASHP. Soil temperature rise of $3^{\circ} \mathrm{C}$ from $26^{\circ} \mathrm{C}$ leads to $43 \%$ increase in the length of GHE. One of the important challenges facing GSHP in hot and dry climates is thermal imbalance [12]. Nabiha Naili et. al [13] study the GSHP system by directly testing and evaluating the potential for using surfacegeothermal energy in air-conditioning applications in Tunisia. The study was conducted at the Center for Research and Technology in Energy (CRTEn) in northern Tunisia, where GSHP was used in the experiment, consisting of a reversible geothermal heat pump (GHP) connected to a horizontal ground heat exchanger (GHE). GSHP connects to the chilled-ceiling panel (CCP) system installed in the test room. Experiment has found that geothermal energy can be used in air conditioning in Tunisia, despite its limited use. The mean test room temperature was reduced by $2^{\circ} \mathrm{C}$ when using GHE. Using the GSHP system is a profitable solution in Tunisia. The study was found that the coefficient of performance (COP) for the whole system and GHE was 3.02 and 4.46, respectively [13]. Jen-Hui Tsai et al [14]. Proved that the use of hot springs in heating was economic. The consumed electrical energy in the building was reduced about $26 \%$, the A/C heating systems was decreased by $54 \%$ of electric energy, and the reduction in electricity consumption by the air host is $66.5 \%$. Expenses 126.7 New Thailand Dollars (NT\$) will produce $1 \mathrm{~kg}$ of carbon-dioxide $\left(\mathrm{CO}_{2}\right)$ emissions [14]. Caterina Frau et al [15], evaluated the techno economic feasibility of a Low - Enthalpy geothermal system for Hybrid Air Conditioning systems. This study found the NPV of the geothermal probe installed into a ground water borehole is positive. Its PBT is 6 years with $65 \%$ of incentive and 9 years without incentive. Debasree Roy et al. [16] presented an investigation of performance and feasibility for vertical GSHP systems that used for cooling and heating application. The study uses the Ground-
Loop Design (GLD) software to perform the GSHP systems design for every location, and use the Energy- Plus v9.0.1 software to simulate the cooling and heating loads of the building [16]. Ahmed Alsamari [17], Samir D. Ali presented an experimental study assessing the use of surface geothermal energy in Iraq for HVAC applications. It was found that the temperature of the earth in the city of Baqubah, at a depth of about $(8 \mathrm{~m})$, reaches $\left(24^{\circ} \mathrm{C}\right)$ throughout the year. Bacoli et.al [18] provided an analysis of geothermal heat pumps used in A/C systems for both Energy and Exergy. Bacoli worked on discovering the properties of the thermal diffusivity and thermal conductivity of the earth and achieving thermodynamic limit conditions. It is competitive compared to other technologies that use atmospheric air as a heat source. When designing a GWHP, thermal dispersion must be considered as a key factor in the design, as demonstrated by digital and field studies [18]. Umberto Lucia et.al [19] explained that the ability to use the earth as a heat source or heat dispersion must be used an innovative and advanced technology, which is GSHP. On the other hand, if GSHP is combined with a system that operates at relatively low temperatures, it will be a highly efficient solution for heating buildings [19].

The objective of this work focuses on studying the possibility of using geothermal energy as a source of clean energy in air conditioning systems and reducing electricity consumption, as traditional air-conditioning systems consume a large portion of electricity in the residential sector. This study was conducted in the climate of Baqubah city-Iraq. Iraq is located in the southwestern part of the continent Asia and the northeastern part of the Arab homeland between longitudes $38.45^{\circ}$ to $48.45^{\circ}$ $\mathrm{E}$ and latitudes $29.05^{\circ}$ to $37.3^{\circ} \mathrm{N}$ [20-22]. Iraq's climate is characterized as variable from humid in the northern and northeastern region to very dry in the western and southern regions and some central regions as shown in figure (1). 


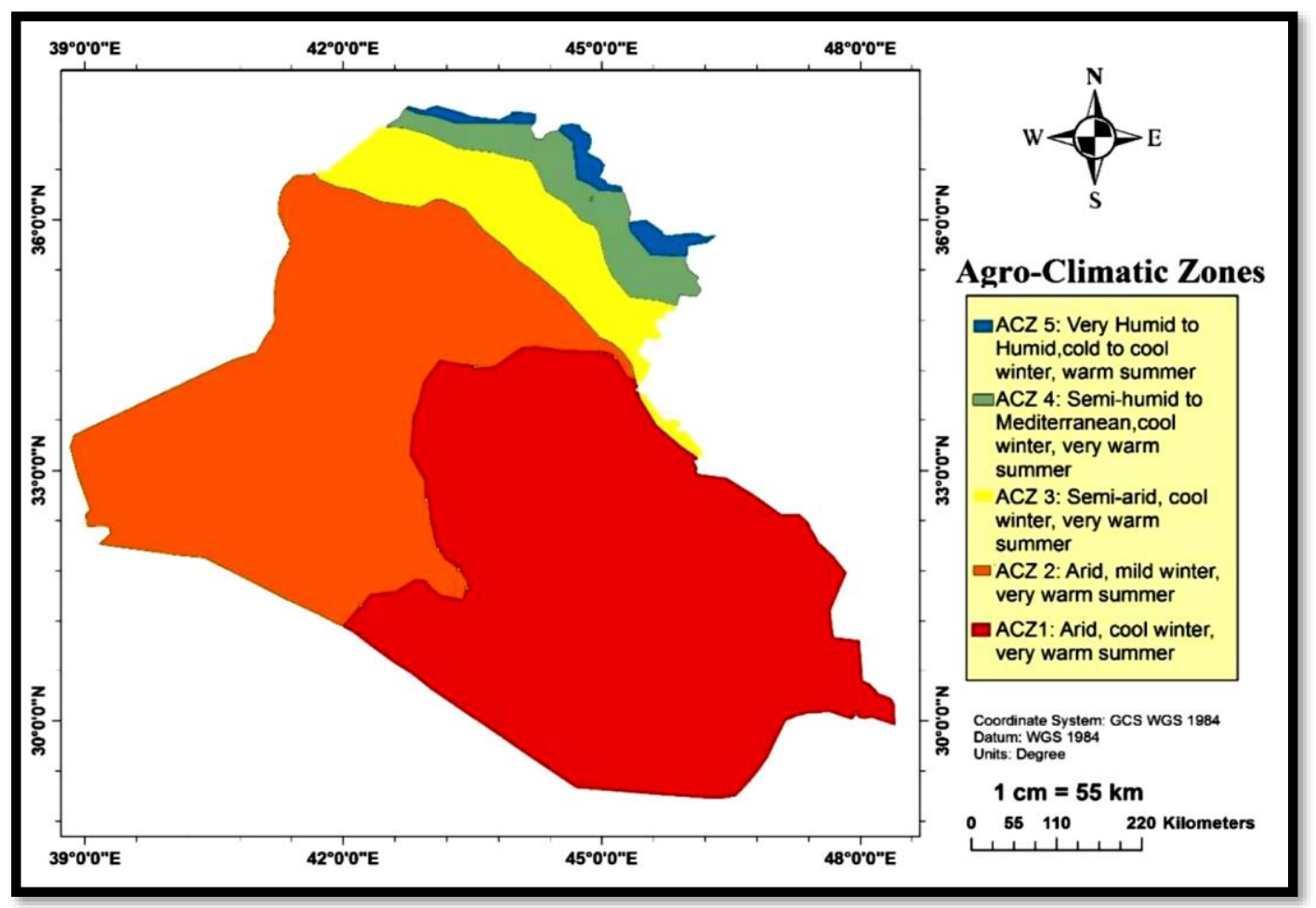

Figure 1. The boundaries of the climatic regions in Iraq according to the Koeppen classification for the period (20012013) [23]

\section{Methodology}

\subsection{Test room}

The study was conducted in the city of Baquba, located in Diyala governorate, within latitude $\left(33^{\circ} .88333 \mathrm{~N}\right)$ and longitude $\left(45^{\circ} .66666\right.$ E).

The study site was chosen to be a living room with dimensions ( $7.25 \mathrm{~m}$ X $3.5 \mathrm{~m} \times 3.2 \mathrm{~m})$ with three internal walls and an outer wall facing west of the northwest (WNW) and containing a metal window with dimensions $(2.5 \mathrm{~m} \times 2 \mathrm{~m})$ with tinted glass. It has two internal doors made of wood with dimensions ( $2.1 \mathrm{~m} \mathrm{X} 1 \mathrm{~m})$.

The theoretical and practical calculations were performed on them using the HAP 4.9 program for their modeling and design equations used in the air conditioning calculations. Water well was drilled in the front garden of the house opposite the test room. At a distance of $(5.5 \mathrm{~m})$ from it to reduce the losses caused by pumping as much as possible. The well was (6 m) deep and (4 in).

The readings were taken for different days of July, which is one of the hottest months of the year, in order to calculate the cooling loads. The readings were taken for different days of December, which is one of the coldest months of the year, to calculate heating loads.

Test days for July's month are $11^{\text {th }}, 12^{\text {th }}$ and $17^{\text {th }}$, while for December are $14^{\text {th }}$ and $25^{\text {th }}$.

\subsection{The borehole}

The Borehole was manually drilled with the drilling tool, after that a PVC pipe with length of (7meters) and a diameter of $(101.6 \mathrm{~mm})$ is inserted into the wellbore. The tube is surrounded by a layer of gravel to prevent the side holes from becoming clogged with silt deposits. Figure (2) shows the shape of the well and its location in the home garden. 
Table 1: Water pump specifications

\begin{tabular}{lc}
\hline Total water pump & Specifications \\
\hline MODEL & PS -126 \\
$\mathrm{H}_{\max }$ & $28 \mathrm{~m}$ \\
$\mathrm{Q}_{\max }$ & $36 \mathrm{~L} / \mathrm{min}$. \\
PHASE & Single \\
Voltage & $220-240 \mathrm{~V}$ \\
Frequency & $50 \mathrm{~Hz}$ \\
Speed & $2850 \mathrm{~min}^{-1}$ \\
Power $(\mathrm{P} 1)$ & $370 \mathrm{~W}$ \\
Input current & $1.8 \mathrm{~A}$ \\
Maximum Suction side $\left(\mathrm{S}_{\mathrm{max}}\right)$ & $8 \mathrm{~m}$ \\
Capacitance & $8 \mu \mathrm{F}$ \\
Class & $\mathrm{I}$ \\
Max ambient temperature & $45^{\circ} \mathrm{C}$ \\
Max water temperature & $50^{\circ} \mathrm{C}$ \\
Duty & Continuous \\
Motor insulation & Class F \\
\hline
\end{tabular}

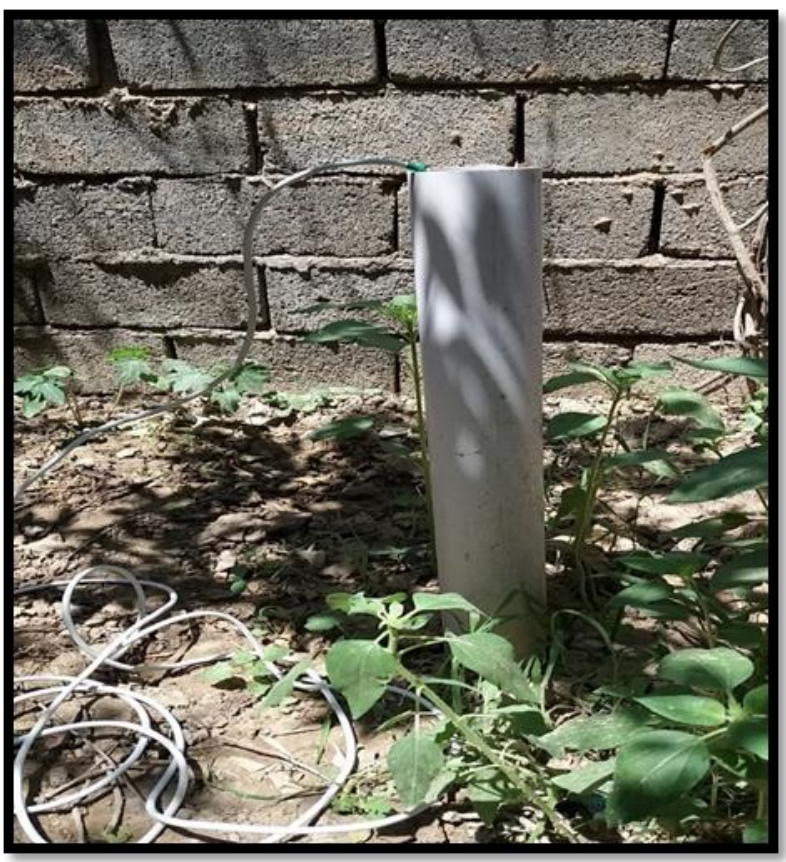

Figure 2. The water-well used in experiment

\subsection{Water pump}

A Tota water pump was used for the purpose of drawing water from the well and pumping it to the geothermal system (heat exchanger + fan). Table (1) shows the specifications of the pump used in the study.

\subsection{Geothermal system (Fan-Coil system)}

The part used to exchange heat with the studied space is a modified external part of LG split unit air-conditioner with capacity of 26000Btuh heating/cooling. The heatexchanger was discharged from the R-22 refrigerant fluid and the invertor valve was also removed to ensure that the flow inside the exchanger tubes was completely. The work of two entry and exit ports for water. As water is the medium that conducts heat from or to the conditioned space. Figure (3) shows the fan coil system. 


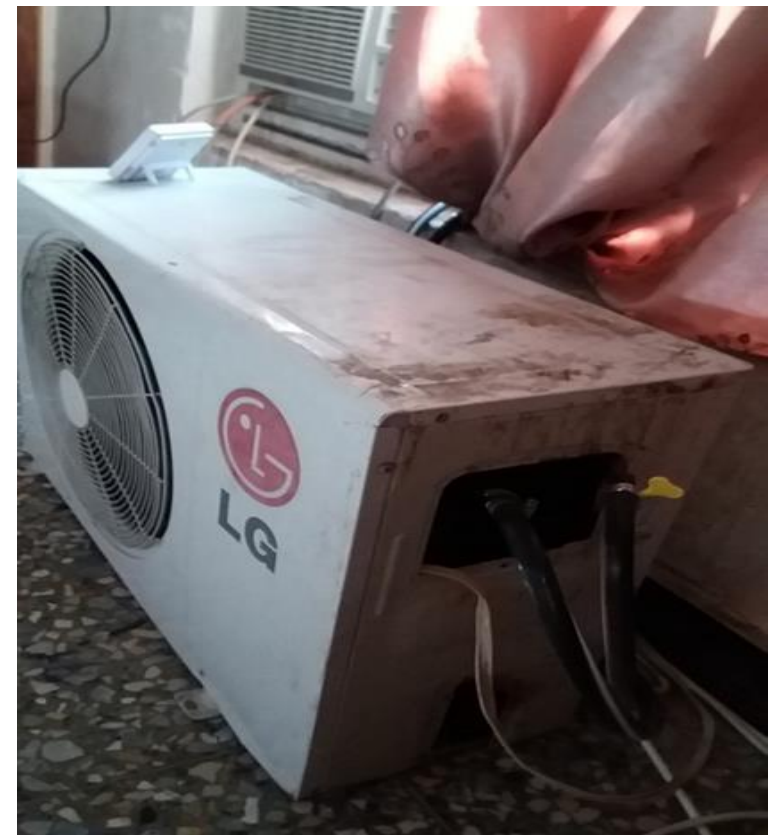

Figure 3. The modified Fan-Coil system

\subsection{Test of geothermal system}

Measurements were made on the air conditioning system consisting of a geothermal system and window type air conditioner. Where the geothermal system was operated throughout the day, while the window-type air conditioner works when the temperature of the test room rises to more than $27^{\circ} \mathrm{C}$ during the cooling season. In the heating season, the geothermal system works continuously during the day, and the traditional air-conditioner works when the room temperature drops below $23^{\circ} \mathrm{C}$. The electrical energy consumption was measured in the summer and winter seasons and compared with the energy consumption of the traditional air-conditioner, as well as compared with the electricity consumption of the geothermal system. Later, the efficiency of each system was calculated separately.

\subsection{Measuring devices}

The measurement tools used in the experiment for the purpose of measuring temperature, humidity and electricity consumption were listed below:

1. A temperature controller of the type STC-200.

2. Relative humidity and temperature meter of the type HTC-2.
3. Single Phase Electronic Meter ME-152 to measure energy consumption in $\mathrm{kWh}$.

\section{Data reduction}

The heat extracted from the test room is calculated by the following equation:

$\mathrm{q}=\dot{\mathrm{m}} \mathrm{C}_{\mathrm{p}}\left(\mathrm{T}_{\mathrm{e}}-\mathrm{T}_{\mathrm{i}}\right)$

Coefficient of performance (COP) of system is the ratio of thermal load to input work.

$\mathrm{COP}_{\mathrm{HP}}=\mathrm{Q}_{\mathrm{H}} / \mathrm{W}$

Energy efficiency ratio (EER) is the ratio of cooling load in Btu/h to electrical energy input (W)

$\mathrm{EER}=\mathrm{Q}_{\mathrm{c}} / \mathrm{W}$

The relation between COP and EER is as bellow:

$\mathrm{EER}=3.412 \mathrm{COP}$

In practice, it is preferred that the EER be higher than 10.

\section{Results and discussions}

Ground temperature is one of the important factors affecting the operation and efficiency of geothermal systems. The increase in the temperature difference between the cooled/heated space and the temperature of the 
ground water leads to an increase in the efficiency of the system. The temperature of the ground in Baqubah city at the depth of 6 meter is still constant about $24^{\circ} \mathrm{C}$ along the year and it is suitable for heating and cooling applications. The ground temperature in summer is lower than the ambient temperature that reaches about $50^{\circ} \mathrm{C}$, so that it is more suitable to use in cooling applications. In winter the temperature of ground is higher than the temperature of ambient that reaches below zero centigrade, so that ground temperature is very good choice to use for heating applications.

Figure (4) shows the distributions of temperatures relative to the borehole depths in both summer and winter seasons.

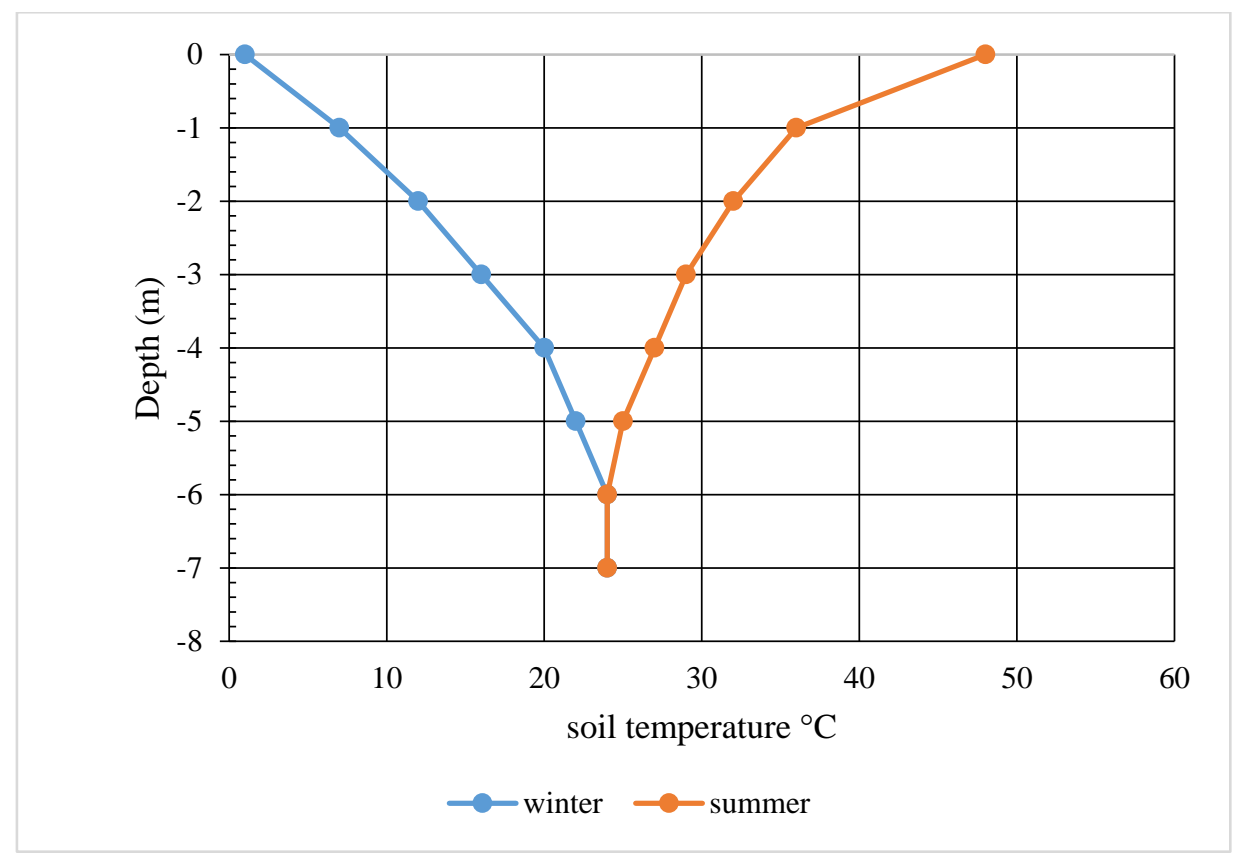

Figure 4. Variation of Borehole Temperature relative to its depth

Table (2) shows EER and COP for three airconditioning systems; geothermal system, window type $\mathrm{A} / \mathrm{C}$ and combined system (Geothermal $+\mathrm{A} / \mathrm{C}$ system). The results show that EER and COP for geothermal system are greater than combined system and window-type $\mathrm{A} / \mathrm{C}$, so that when EER and COP increased the energy consumption by the system decreased.

Table 2. Systems cooling load, heating load, input power, COP and EER

\begin{tabular}{lccccc}
\hline System & $\begin{array}{c}\text { Cooling load QC } \\
(\mathbf{k W})\end{array}$ & $\begin{array}{c}\text { Heating load } \\
\mathbf{Q}_{\mathbf{h}}(\mathbf{k W})\end{array}$ & $\begin{array}{c}\text { Power input } \\
\mathbf{W}_{\mathbf{c}} / \mathbf{W}_{\mathbf{h}}(\mathbf{k W})\end{array}$ & $\begin{array}{c}\text { EER } \\
(\mathbf{B t u} / \mathbf{h} / \mathbf{W})\end{array}$ & $\begin{array}{c}\mathbf{C O P} \\
(\mathbf{W} / \mathbf{W})\end{array}$ \\
\hline Geothermal & 2.23 & 2.23 & $0.4026 / 0.4026$ & 18.9 & 5.54 \\
A/C & 7 & 6.22 & $2.5500 . / 4.100$ & 9.4 & 1.52 \\
A/C+ Geothermal & 7 & 6.22 & $2.45 / 3.3$ & 9.8 & 1.9 \\
\hline
\end{tabular}

The most important factors that effect on the cooling/heating loads are the ambient temperature and relative humidity. Figures (5), (6), (7), (8), (9) and (10) shows the behaviours of temperature and relative humidity distribution for test room indoor and outdoor in July 2020 for the three cases. Figures from (5) to (10) show the temperature change during the days of July, which is considered one of the hottest months of summer, as the harshness of the hot and dry climate in Baqubah city becomes clear through the temperatures and relative humidity recorded during July. This rise in temperature in the current decade compared to the temperatures recorded by meteorological stations in the past decades is due to the causes 
of global warming and climate change taking place in all parts of the globe. The using of geothermal system in July achieves a temperature difference between the outdoor and indoor by an amount about $13^{\circ} \mathrm{C}$ as shown in figure (7), and this difference is considered good in air-conditioning applications. On the other hand, due to the inability of the geothermal system alone to remove moisture, it does not achieve suitable comfort conditions, so it is preferable to continue studying in the future for the purpose of improving the system to provide comfort conditions.

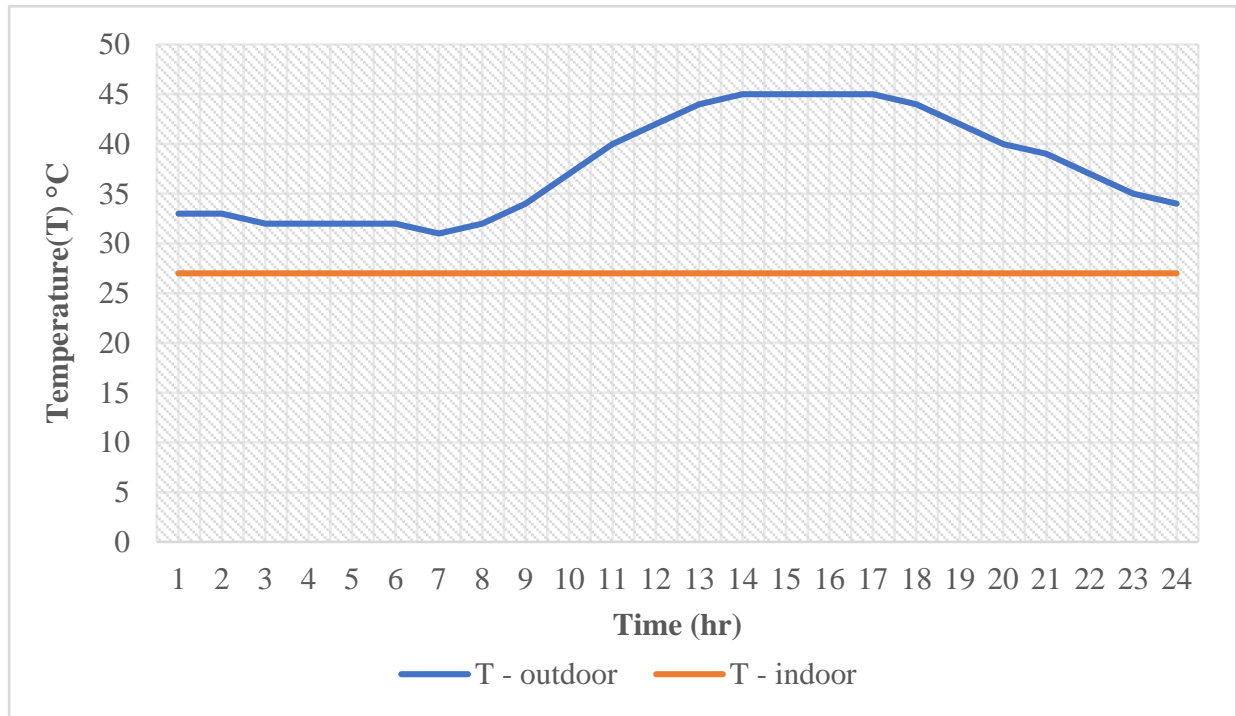

Figure 5. Temperature distribution for rooms indoor and outdoor at 11th July 2020 (A/C +geothermal system)

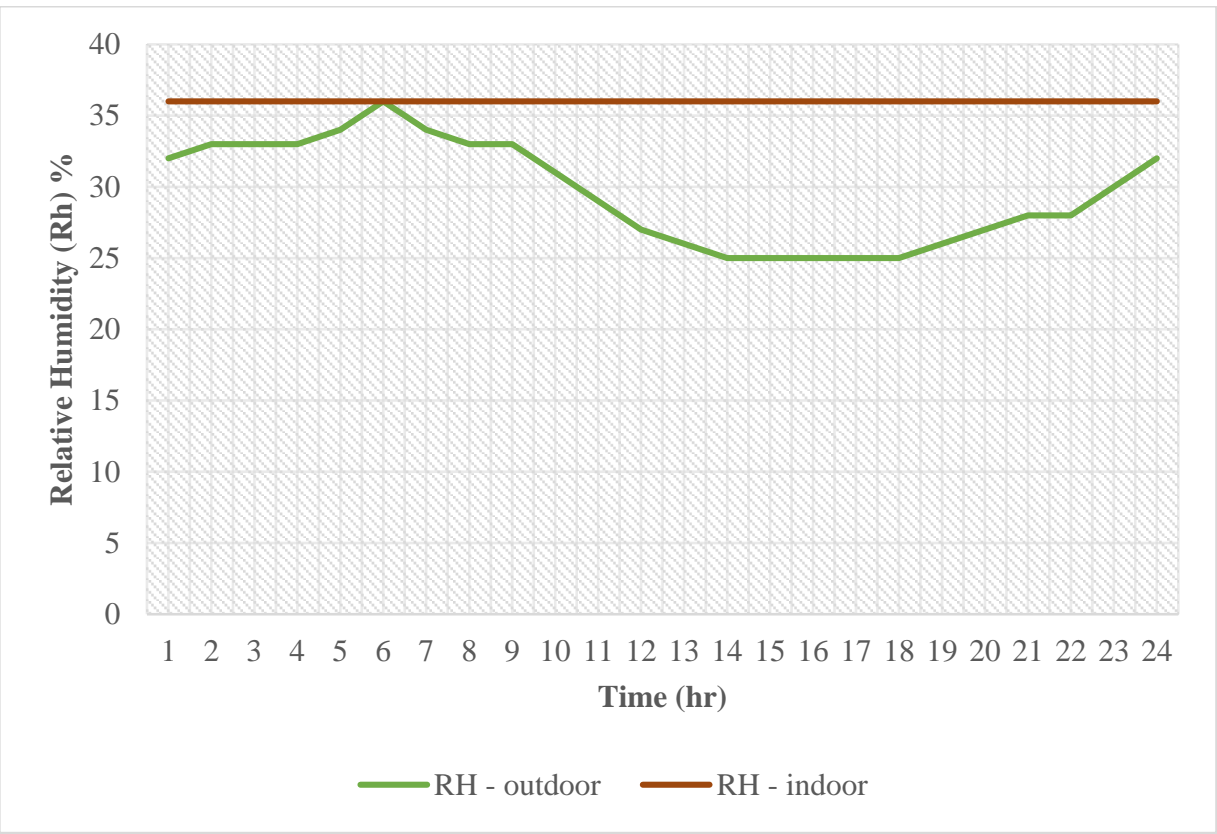

Figure 6. Relative humidity (RH) distribution for rooms indoor and outdoor at 11 th July 2020 (A/C +geothermal system) 


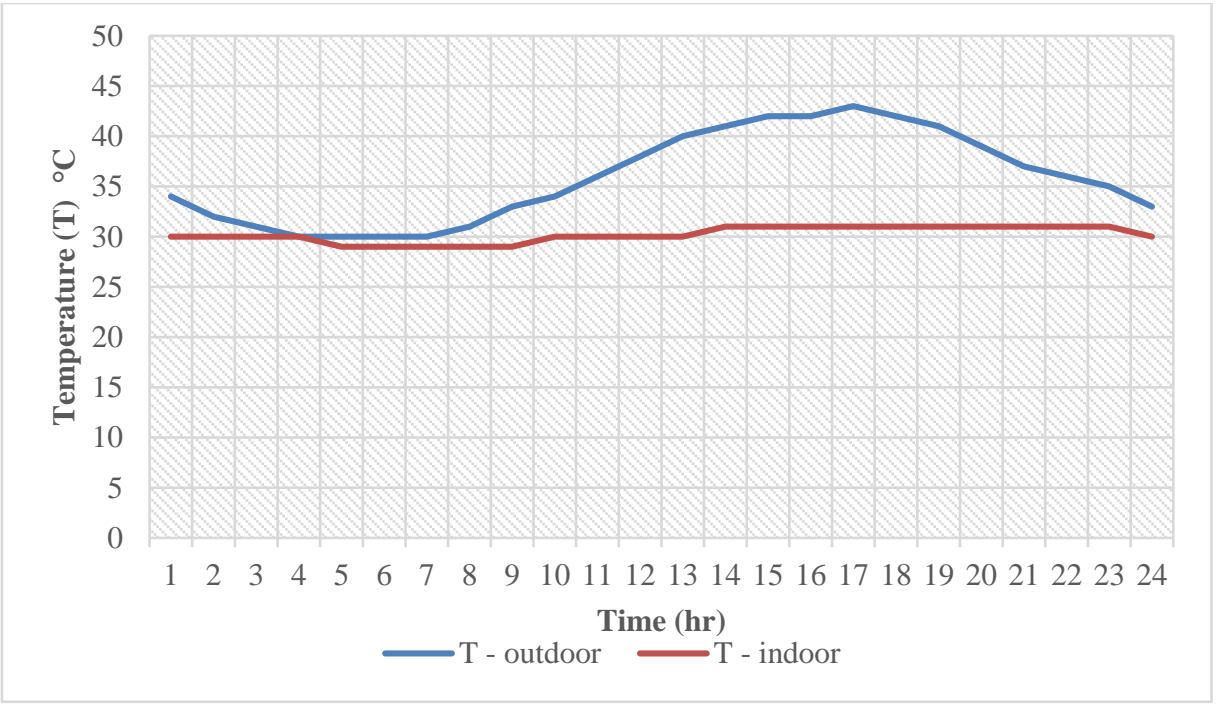

Figure 7. Temperature distribution for rooms indoor and outdoor at 12th July 2020 (geothermal system only)

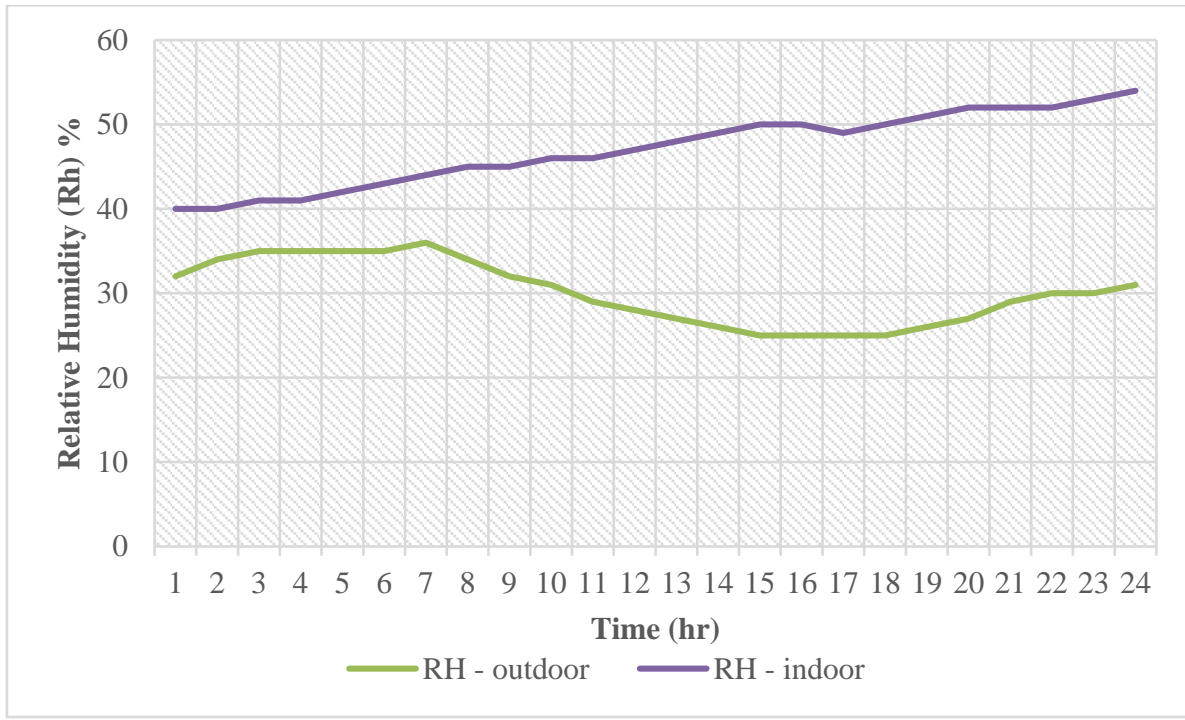

Figure 8. Relative humidity (RH) distribution for rooms indoor and outdoor at 12th July 2020 (geothermal system only)

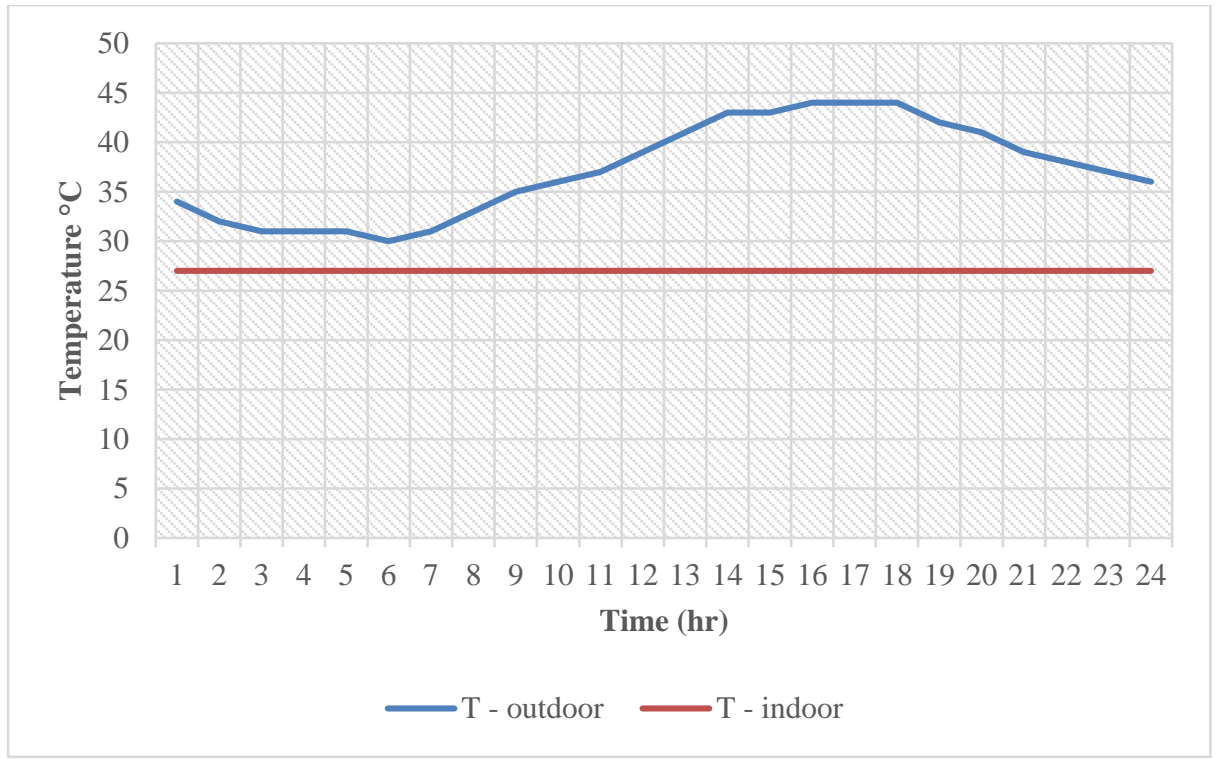

Figure 9. Temperature distribution for rooms indoor and outdoor at 17th July 2020 (A/C system only) 


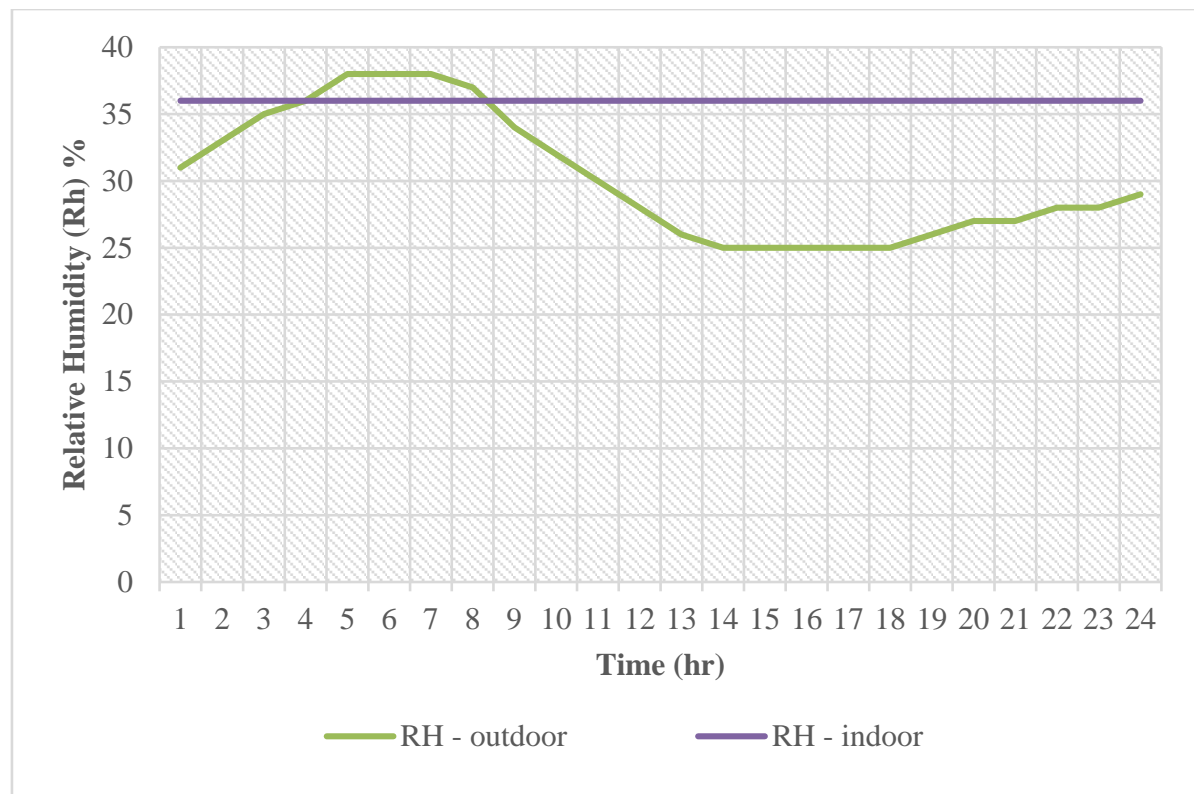

Figure 10. Relative humidity $(\mathrm{RH})$ distribution for rooms indoor and outdoor at 17 th July 2020 (A/C system only)

Figure (11) shows the electric energy consumption in $\mathrm{kWh}$ for the three systems during the summer season.

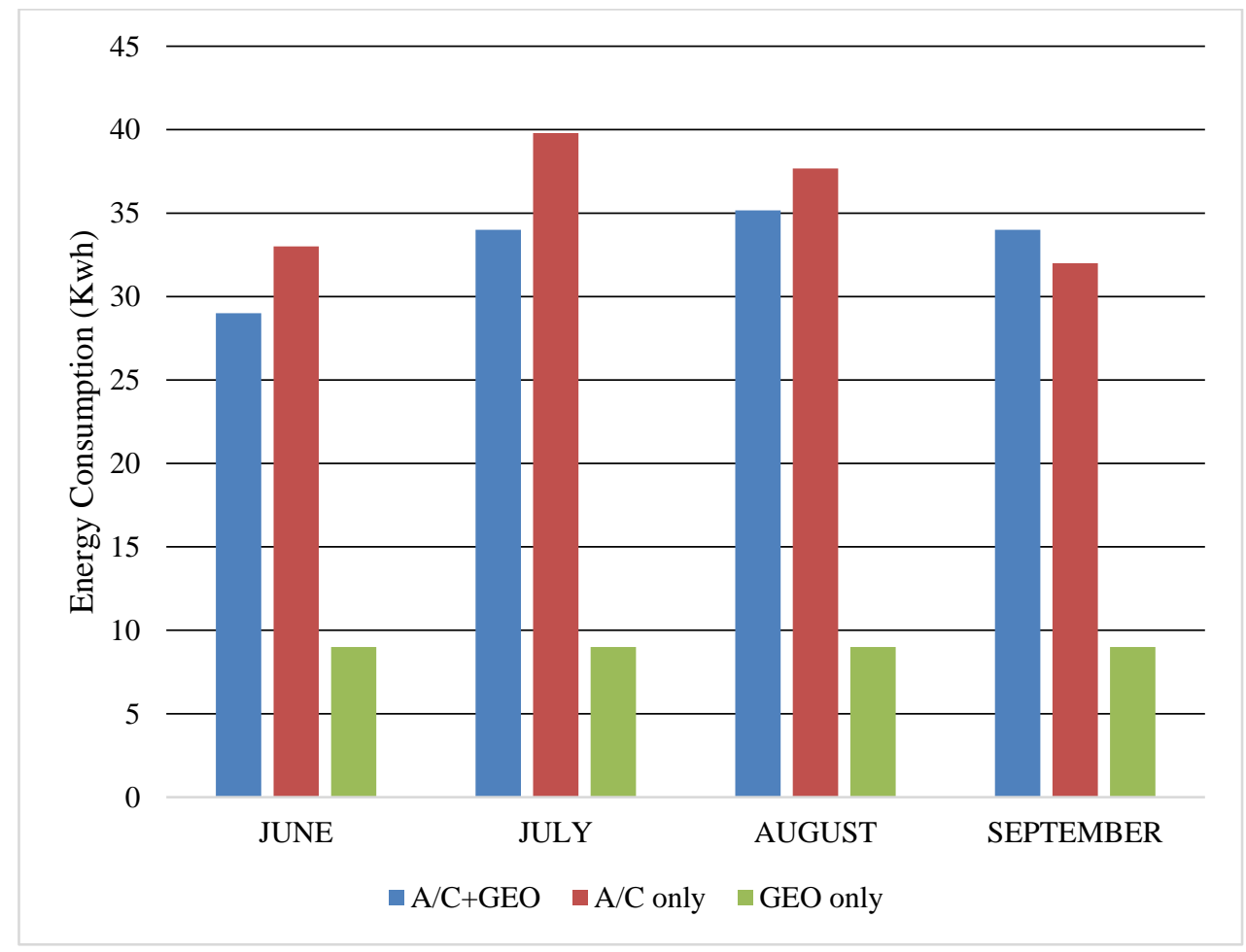

Figure 11. Energy consumption in summer season

Figure (12) shows the combined system's energy saving in summer months, where it is noted that the highest rate of energy savings occurs in July. In September, energy is wasted by $6.25 \%$ due to the additional load on the system as a result of the latent load generated due to high humidity. 


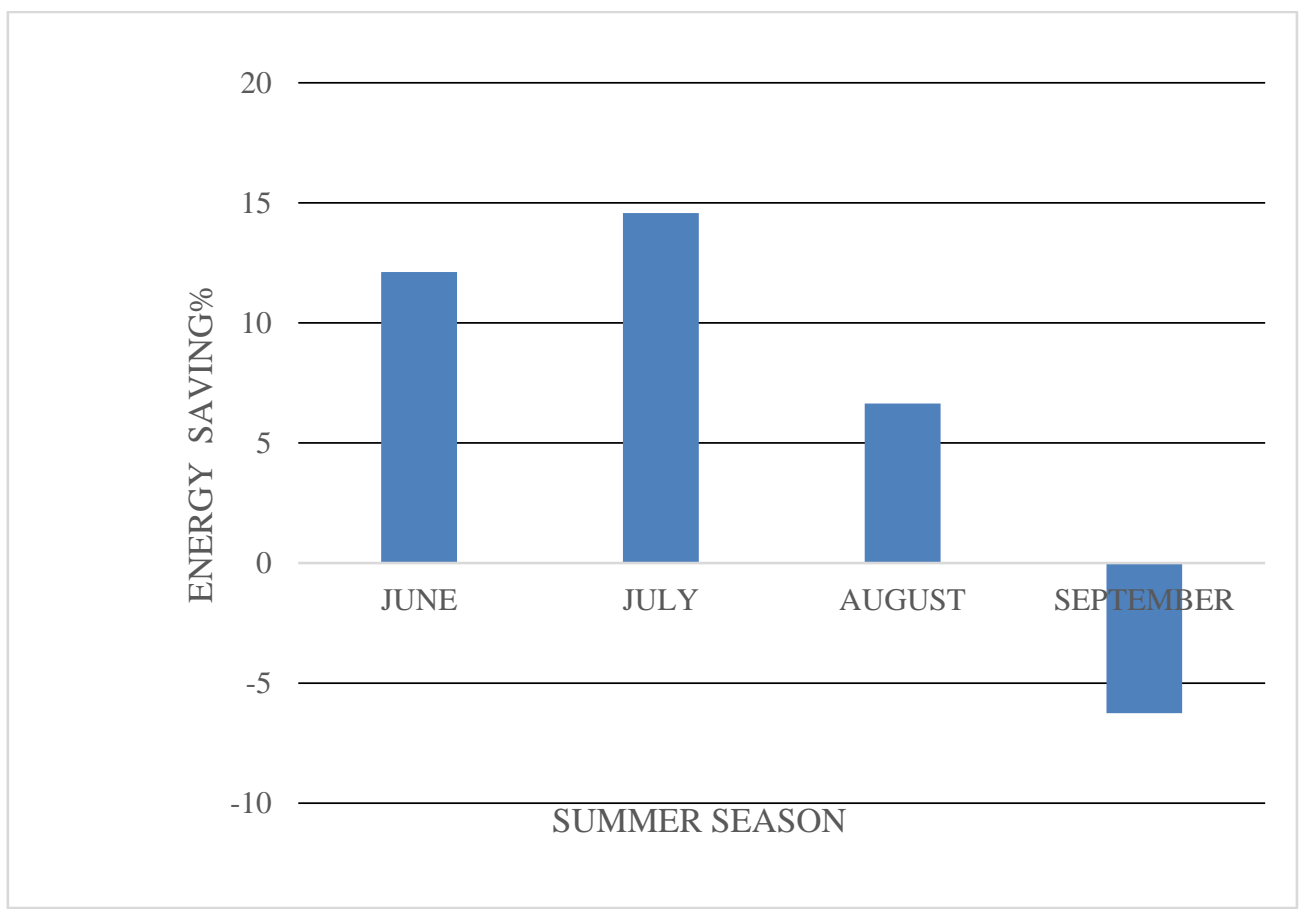

Figure 12. Energy saving in summer season for combined system compared to A/C

The relative humidity $(\mathrm{RH})$ and temperature distributions' behaviours are shown in figures (13), (14), (15) and (16) for combined system and geothermal system in December 2020 for indoor and outdoor. . Figures from (13) to (16) show the temperature change during the days of December, which is considered one of the coldest months of winter, as the harshness of the cold and humid climate in winter in Baqubah city becomes clear through the temperatures and relative humidity recorded during December. There is a rise in temperature in the current decade compared to the temperatures recorded by meteorological stations in the past decades due to the causes of global warming and climate change taking place in all parts of the globe.

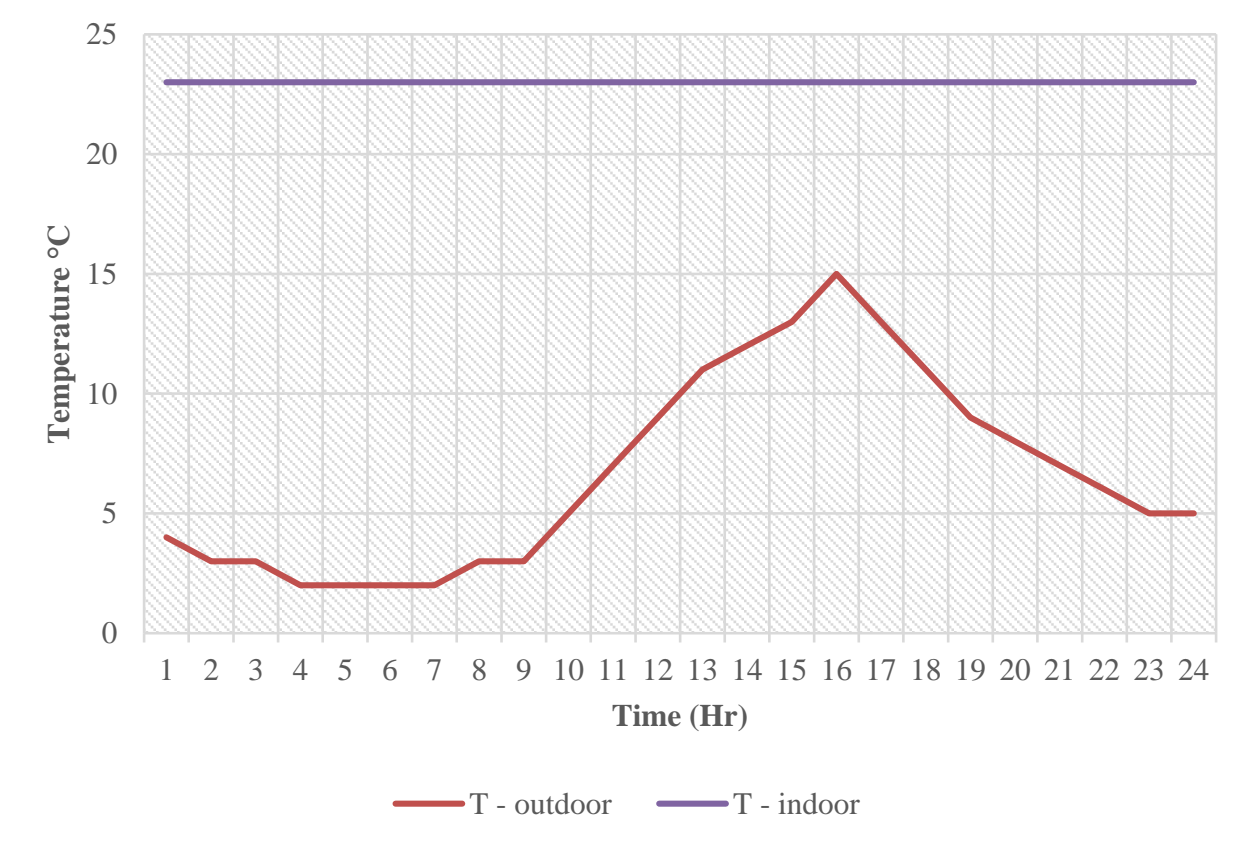

Figure 13. Temperature distribution for rooms indoor and outdoor at 25th December 2020 (A/C +geothermal system) 


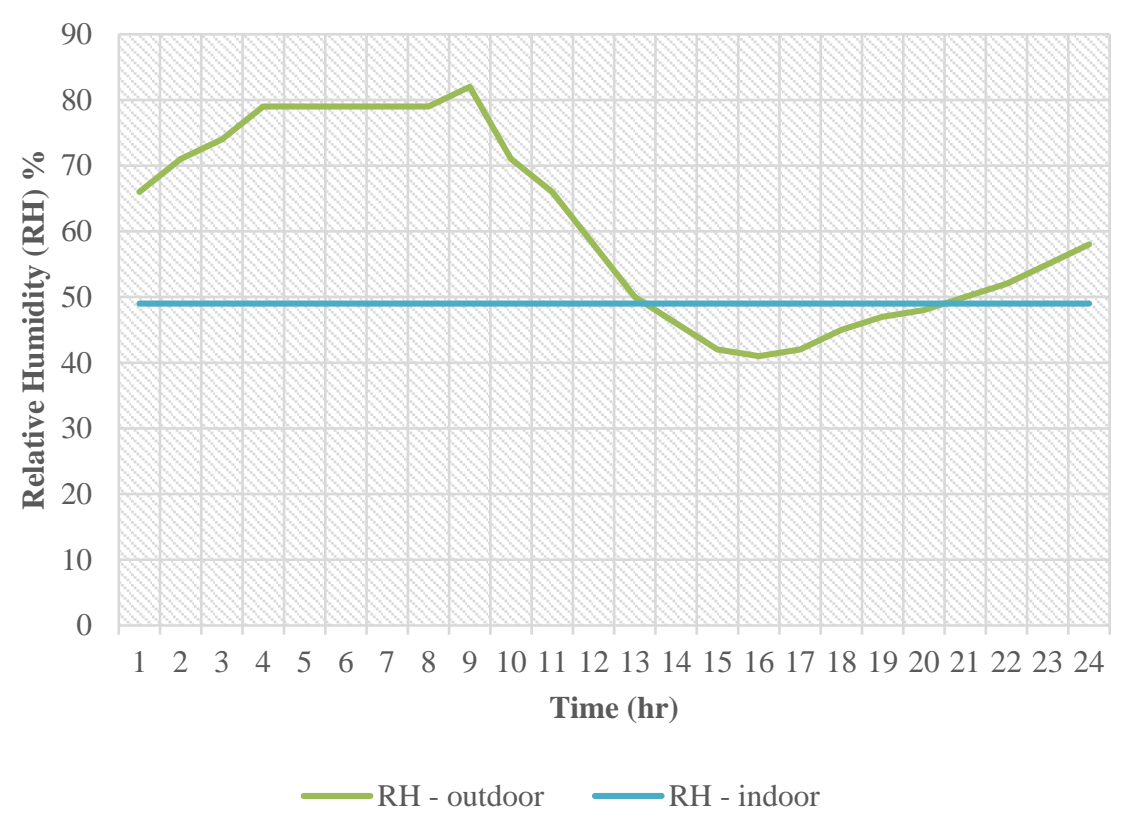

Figure 14. Relative humidity $(\mathrm{RH})$ distribution for rooms indoor and outdoor at 25th December 2020 (A/C +geothermal system)

Using the geothermal system for heating in December achieves a temperature difference between outdoor and indoor by an amount about $13^{\circ} \mathrm{C}$ as shown in figure (15), and this difference is considered good in air-conditioning applications. On the other hand, the geothermal system alone has achieved suitable comfort conditions and contributed to reducing energy consumption by $84 \%$.
This study contributed to a reduction of electrical energy consumption by $84 \%$ when using geothermal energy, compared with the study of Al-Samari, which contributed to a reduction of electrical energy consumption by $60 \%$, and the Al-Shehri study, which reduced electricity consumption by $34.6 \%$.

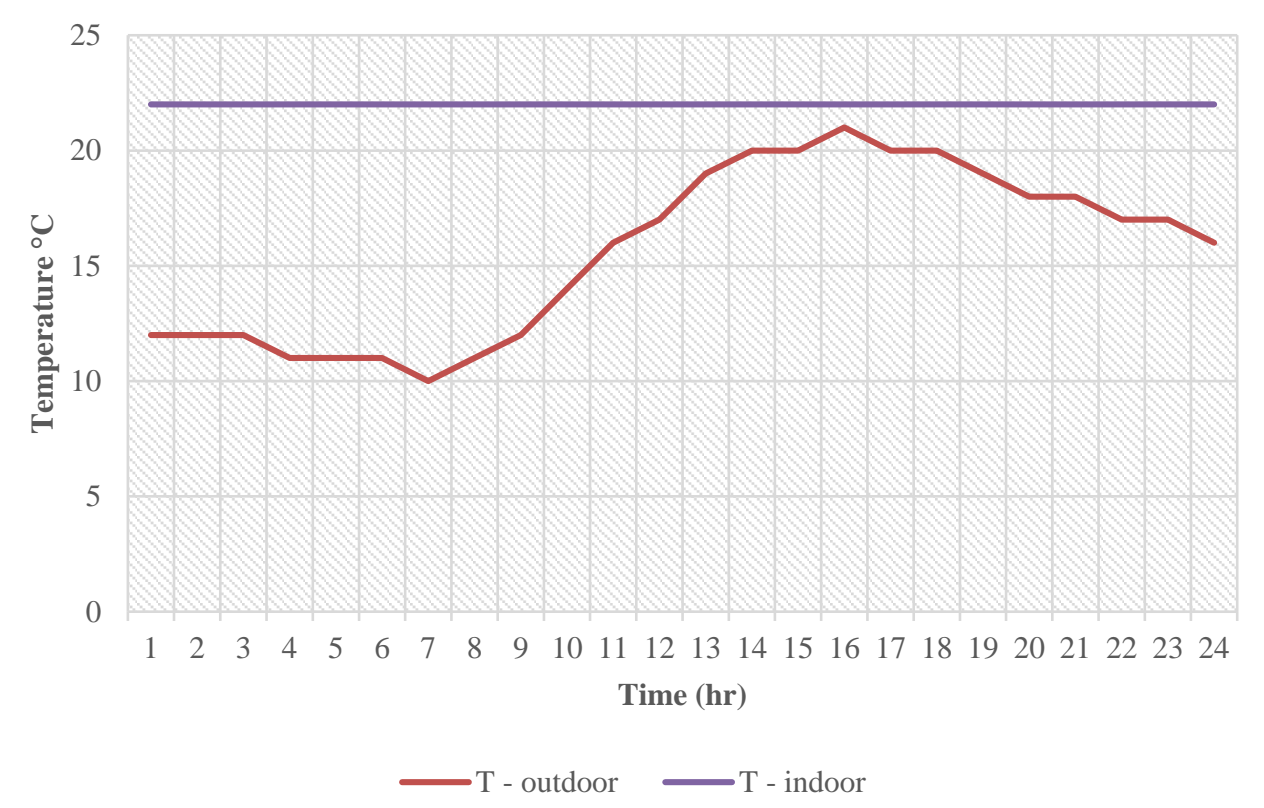

Figure 15. Temperature distribution for rooms indoor and outdoor at 14th December 2020 (geothermal system only) 


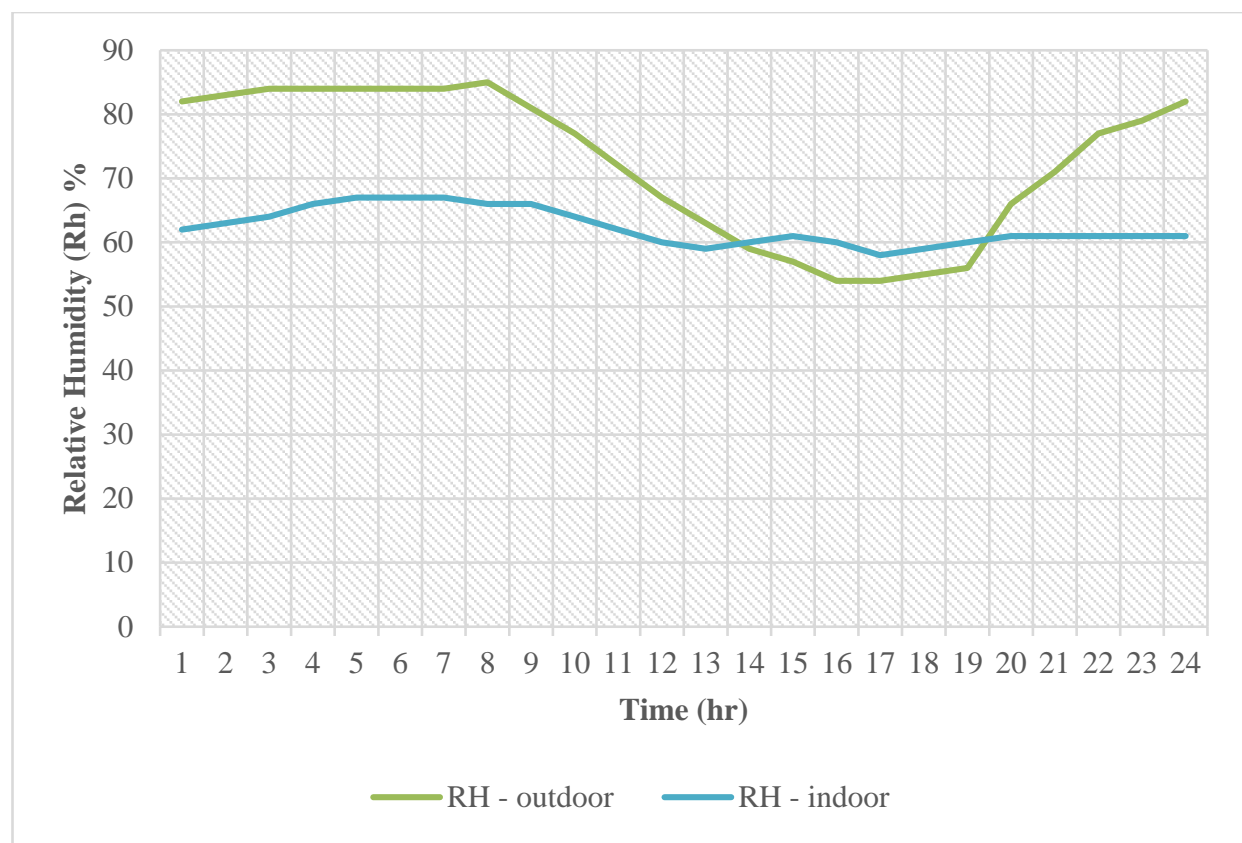

Figure 16. Relative humidity (RH) distribution for rooms indoor and outdoor at 14th December 2020 (geothermal system only)

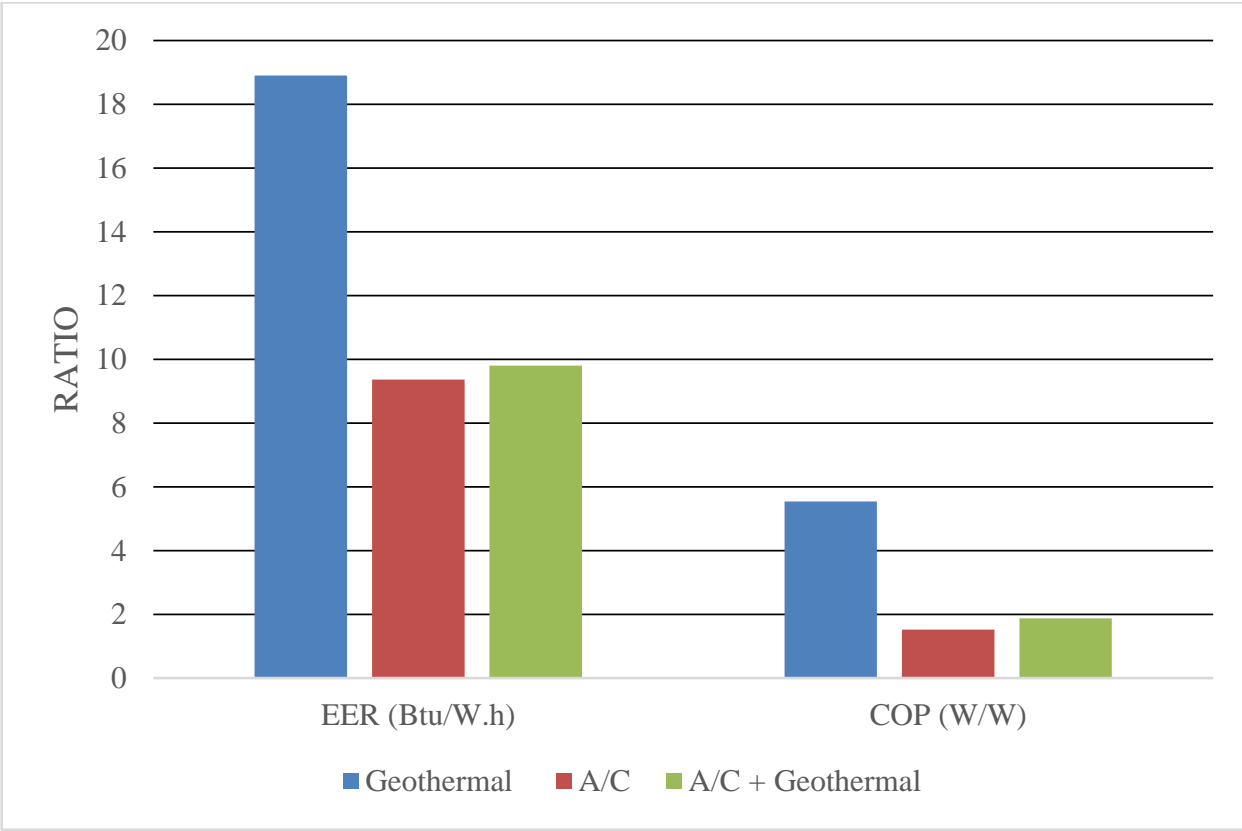

Figure 17. Energy Efficiency Ratio (EER) and Coefficient of Performance (COP) for three system

\section{Conclusions}

The results of the experiment showed:

1- The possibility of using geothermal energy in air-conditioning in Iraq, which reduces electricity consumption.

2- Achieving economic feasibility in the foreseeable future.

3- Reducing environmental pollution from using fossil fuels to generate electricity.
4- Continuing to search in the field of geothermal energy to get the best results in air-conditioning applications.

\section{Acknowledgement}

The authors thank everyone who contributed to facilitating the completion of this research, especially the Department of Mechanical Engineering, University of Diyala. 


\section{References}

[1] Picard, Damien. "Modeling, optimal control and HVAC design of large buildings using ground source heat pump systems." (2017).

[2] Carvalho, Anabela Duarte. "High efficiency ground source heat pump systems for sustainable building space conditioning." PhD diss., 2015.

[3] Pérez-Lombard, Luis, José Ortiz, and Christine Pout. "A review on buildings energy consumption information." Energy and buildings 40, no. 3 (2008): 394-398.

[4] Stober, I. and K. Bucher, History of geothermal energy use, in Geothermal Energy. 2013, Springer. p. $15-24$.

[5] Council, E.G.E., 2016 EGEC geothermal market report, in Tech. rep.,2016 2016.

[6] Lee, Chulho, Sangwoo Park, Hyun-Jun Choi, In-Mo Lee, and Hangseok Choi. "Development of energy textile to use geothermal energy in tunnels." Tunnelling and Underground Space Technology 59 (2016): 105-113.

[7] Johnston, I. W., G. A. Narsilio, and S. Colls "Emerging geothermal energy technologies." KSCE Journal of Civil Engineering 15, no. 4 (2011): 643 653.

[8] Park, Sangwoo, Seokjae Lee, Hyobum Lee, Khanh Pham, and Hangseok Choi. "Effect of borehole material on analytical solutions of the heat transfer model of ground heat exchangers considering groundwater flow." Energies 9, no. 5 (2016): 318

[9] Loveridge, F., The thermal performance of foundation piles used as heat exchangers in ground energy systems. 2012, University of Southampton.

[10] Pasquier, Philippe, and Denis Marcotte. "Short-term simulation of ground heat exchanger with an improved TRCM." Renewable energy 46 (2012): 92 99.

[11] Choi, Hyun-Jun, Sangwoo Park, Hyungi Lee, Khanh Linh Nguyen Pham, Hyungkyou Ryu, and Hangseok Choi. "Optimum operation of open-loop ground heat exchanger considering subsurface temperature gradient." International Journal of Energy Research 40, no. 5 (2016): 651-661.

[12] Alshehri, Faisal, Stephen Beck, Derek Ingham, Lin Ma, and Mohammed Pourkashanian. "Technoeconomic analysis of ground and air source heat pumps in hot dry climates." Journal of Building Engineering 26 (2019): 100825.

[13] Naili, Nabiha, Majdi Hazami, Issam Attar, and Abdelhamid Farhat. "Assessment of surface geothermal energy for air conditioning in northern Tunisia: direct test and deployment of ground source heat pump system." Energy and Buildings 111 (2016): 207-217.
[14] Tsai, Jen-Hui, Chin-Pao Wu, and He-Chien Chang. "An investigation of geothermal energy applications and assisted air-conditioning system for energy conservation analysis." Geothermics 50 (2014): 220226.

[15] Frau, Caterina, Enrico Maggio, Francesca Poggi, Emanuela Melis, Francesco Floris, and Pier Francesco Orrù. "Low-enthalpy geothermal systems for air conditioning: a case study in the Mediterranean climate." Energy Procedia 148 (2018): 527-534.

[16] Roy, Debasree, Tanusree Chakraborty, Dipanjan Basu, and Bishwajit Bhattacharjee. "Feasibility and performance of ground source heat pump systems for commercial applications in tropical and subtropical climates." Renewable Energy 152 (2020): 467-483.

[17] Al-Samari, Ahmed SH, and Sameer D. Ali. "Experimental evaluation of surface geothermal energy for air conditioning applications in Iraq." Journal of Mechanical Engineering Research and Developments 41, no. 1 (2018): 38-43.

[18] Baccoli, Roberto, Costantino Mastino, and Giuseppe Rodriguez. "Energy and exergy analysis of a geothermal heat pump air conditioning system." Applied Thermal Engineering 86 (2015): 333-347.

[19] Lucia, Umberto, Marco Simonetti, Giacomo Chiesa, and Giulia Grisolia. "Ground-source pump system for heating and cooling: Review and thermodynamic approach." Renewable and Sustainable Energy Reviews 70 (2017): 867-874.

[20] Abbas, Malik R., MahIr Mahmod Hason, Baharin Bin Ahmad, and Talib R. Abbas. "Surface roughness distribution map for Iraq using satellite data and GIS techniques." Arabian Journal of Geosciences 13, no. 17 (2020): 1-13.

[21] Abbas, Malik R., Mahir Mahmod Hason, Baharin Bin Ahmad, and Talib R. Abbas. "Variations Size Investigation in Vegetation and Surface Water Body for Central Part of Iraq using Satellite Imagery Bands." In IOP Conference Series: Materials Science and Engineering, vol. 928, no. 2, p. 022064. IOP Publishing, 2020.

[22] Salman, Saleem A., Shamsuddin Shahid, Tarmizi Ismail, Eun-Sung Chung, and Alaa M. Al-Abadi. "Long-term trends in daily temperature extremes in Iraq." Atmospheric research 198 (2017): 97-107.

[23] Alwan, I.A., H.H. Karim, and N.A. Aziz. Agroclimatic zones (ACZ) using climate satellite data in Iraq republic. in IOP conference series: Materials Science and Engineering. 2019. IOP Publishing. 